\title{
Polymorphism Diacylglycerol Acyltransferase 1 (DGAT1) Gene in Bali Cattle
}

\author{
Alwiyah $^{1}$, Nuraini $\mathrm{H}^{2}$, Agung $\mathrm{PP}^{3}$, Jakaria ${ }^{2}$ \\ ${ }^{1}$ Indonesian Goat Research Station, PO Box I Sungai Putih, Galang 20585, North Sumatra \\ ${ }^{2}$ Faculty of Animal Sciences, Bogor Agriculture University \\ Jl. Agatis Dramaga, Bogor 16640, Indonesia \\ ${ }^{3}$ Research Center for Biotechnology, Indonesian Institute of Science \\ Jl. Raya Bogor Km. 46, Cibinong 16911, Indonesia \\ nawal_alwiyah@yahoo.co.id
}

\begin{abstract}
Bali cattle is a native cattle from Indonesia that has tremendous potential to be developed. However, the utilization is not yet optimal. Carcass quality is one of the unoptimized traits and molecular approach is used to study this trait. One of the markers that can be used to study carcass quality is Diacylglycerol Acyltransferase 1 (DGAT) gene. The purpose of this study was to identify the diversity of Diacylglycerol Acyltransferase 1 (DGAT) gene in Bali cattle at Bali Cattle Breeding Center. Sequencing method and defining the right SNP on the target fragment of DGAT1 gene were used for this study. The number of samples used in this study were 48 heads of Bali cattle consisting of 24 males and 24 females. Primer DGAT1 gene amplification used forward 5'-CACCATCCTCTTCCTCA-3' and reverse 5'-GGAAGCGCTTTCGGATG-3'. Identification of DGAT1 gene diversity was conducted by direct sequencing of allele and genotype methods. Hardy-Weinberg balance was calculated by GENEPOP (V3.2). The result of analysis found SNP in DGAT1 gene in Bali cattle. There were SNP c.10433G > A and c.10434C> A, but they were monomorphic.
\end{abstract}

Key Words: Bali Cattle, DGAT1 Gene, SNP

\section{INTRODUCTION}

A demand for meat in Indonesia increases every year, but the meat production national is still deficit, so that it is overcomed by import. Meat needs in Indonesia in 2017 reached 604,968 tons while meat production produced reached 354,770 tons (BPS 2017). Of course, to fulfill the meat needs, the Government havr to import meat. Increasing number of cattle should be accompanied by increasing the meat quality. One of the factors that use to determine meat quality is marbling. Marbling is a composition of fat in the intramuscular (Soeparno 2005). Increasing of meat quality should be done in native livestock and local livestock, including Bali cattle.

Bali cattle (Bos javanicus) as native cattle in Indonesia, originaled from domestication of bull (Bibos banteng) (Purwantara 2012) is genetic resource that has been recognized by FAO as one of the beef cattle breed in the world (DGLS 2003). Bali cattle has some superior characters, able to adapt to the marginal environment and posses high reproductive performance especially in low quality feed (Talib 2002). In various aintenance conditions in Indonesia, Bali cattle still show ability to reproduce. Bali cattle has high carcass percentage $48-52 \%$ (Ismail et al. 2014), water binding capacity $66.2 \%$ (Dewitri et al. 2015), cooking loss $19-28 \%$, tenderness $3-3.5 \mathrm{~kg} / \mathrm{cm}^{2}$ and having protein level 17-21\% (Eko \& Subandriyo 2004).

One of the efforts to improve quality genetic resources of Bali cattle is to do a selection to obtain genetic characteristics found on Bali cattle such as good carcass quality. 
Commonly, breed selection refers to phenotypic only. But, selection needs to be done genetically with Markers Assisted Selection (MAS). Approach by MAS can be done by using a gene responsible for carcass quality such as SREBP (Barton et al. 2010), DGAT1 (Winter et al. 2002). Previous research studied about the DGAT1 gene using Polymorphism Chain Reaction - Restriction Fragment Length Polymorphism (PCRRFLP) method on Simmental cattle (Winter et al. 2002). Location of Diacylglycerol Acyltransferase 1 gene (DGAT) on cattle is in chromosomes 14 and gene that encodes microsomal enzyme for the final stages of triglycerides synthesis (Xin Li et al. 2013). Lysine/alanine substitution (K232A) in DGAT1 genes has been proven to be associate with milk fat content (Grisart et al. 2002). DGAT1 gene has an association with marbling in the meat (Xin Li et al. 2013). Based on the results research, Utama (2013) on the dairy cattle population in Balitnak and BIB Lembang that DGAT1 gene is polymorphic located on the $14^{\text {th }}$ autosomal chromosome with a total length of 411 base pairs. The amplicon is located at the $10^{\text {th }}$ base position 232 to the $10^{\text {th }}$ base 644 . Alel obtained from this population are the $\mathrm{K}$ and $\mathrm{A}$ alleles. The results of the identification of DGAT1 gene segment diversity in the Center of Dairy Farming (BBPTUSP) Baturraden and Development Center of Dairy Cattle (BPPT SP) Cikole, shows that the DGAT1 gene segment is polymorphic because there are two types of alleles, namely the $\mathrm{K}$ and $\mathrm{A}$ allele (Sari et al. 2014).

It has been confirmed that mutations in DGAT1 was responsible for the increase in milk production, milk fat, milk proteins, fat and protein contained in dairy cows (Grisart et al. 2004). According to Thaller et al. (2003) gene diacylglycerol O-acyltransferase 1 (DGAT1) gene is used as a marker for intramuscular and subcutaneous fat formation. Ribeca et al. (2014) get the genotype at the AA/AA, AA 0.05/GC and GC/GC 0.51 0.44, with a minor allele frequency (AA) i.e. 0.3 and $0.70 \mathrm{GC}$ alleles. Winter et al. (2002) stated that the beef Simmental heifers and bulls both have the genotype AA frequency i.e. 0.00 . Previous research stated that the alleles A/A are commonly owned by the Bos indicus (Winter et al. 2002) and intermediate frequency if it is a cross of Bos indicus $\mathrm{x}$ Bos taurus (Fortes et al. 2009). In several studies mentioned $\mathrm{G} / \mathrm{C}$ allele frequencies associated directly with the resulting flavor (Moore et al. 2003).

Genetic diversity information relate to the genes that control the quality of the carcass on the Bali cattle is still limited studied. Therefore, the diversity of genes DGAT1 at Bali cattle have to be studied using Polymerase Chain Reaction (PCR) with direct sequencing. The results of this research are expected to be the basic information that can be utilized for breeding programs and conservation of Bali cattle.

\section{MATERIAL AND METHODS}

\section{Animals}

Bali cattle blood samples were taken from 48 heads in BPTU-HMT Bali cattle in Bali Province with average age 12-15 months of cattle that raised. The number of males and females each was 24 heads. Cattle were reared in the same paddock and fed with the same type of forage (Pennisetum purpureum and Phaspalum notatum) 10\% and concentrate at $1 \%$ of body weight, respectively. 


\section{Total DNA extraction}

DNA extraction was done based on DNA extraction Kit Geneaid procedures are modified. The method consisted of sample preparation, lysis sel, DNA binding, wash and DNA elution. The quality of total genome extractions was performed on $1 \%$ agarose gel electrophoresis and was checked by spectrophotometry.

\section{Amplification of DNA}

Fragments of genes DGAT1 amplification by PCR technique. DGAT1's Primer forward 5'-CACCATCCTCTTCCTCAAG-3' dan reverse 5'GGAAGCGCTTTCGGATG-3'. Sample DNA extraction yield as much as $1 \mu \mathrm{L}$ PCR tubes was put in and then added $49 \mu 1$ premix solution. Premix made up $0.3 \mu 1$ primer, $23.4 \mu \mathrm{LW}, 25 \mu \mathrm{l}$ Green Master Mix. This mixture is then vortexed and centrifugated using spin down, then incubated within the thermocycler to amplification. PCR conditions i.e. include pre-denaturation $95^{\circ} \mathrm{C} 5$ minutes, followed by denaturation step at $95^{\circ} \mathrm{C}$ annealing 10 seconds, at a temperature of $50^{\circ} \mathrm{C}$ for 20 seconds, the elongation at a temperature of $72^{\circ} \mathrm{C}$ for $30 \mathrm{sec}$ and a final elongation at a temperature of $72^{\circ} \mathrm{C}$ for 5 minutes. The process of DNA amplification was performed up to 35 cycles. The results of the PCR product DGAT1 was applied on agarose gel $1.5 \%$. Agarose gel made to use 0.45 grams of agarose added $30 \mathrm{ml} 0.5 \mathrm{x}$ TBE is then heated in the microwave for 3 minutes. Agarose gel solution was homogenized using magnetic stirrer. EtBr is then added as much as $2.5 \mu \mathrm{l}$. The agarose solution put into printers gel and left until hardened. As many as $5 \mu \mathrm{l}$ of PCR products inserted into wells of the gel and markers $100 \mathrm{bp}$ DNA inserted into the well far left. The next process gel electrified at 100 Volts voltage for 3045 minutes. The process of electrophoresis gel next visualitation help to use UV light UV machine at transilluminator. The results of electrophoresis will show a tape-a tape with a length of DNA fragments. Sequencing samples of Bali cattle will be done using the service from $1^{\text {st }}$ Base in Selangor, Malaysia.

\section{Data analysis}

The analysis was performed on the results of a sequence program BioEdit (Hall 1999) and analyzed to use the method of BLAST (www.ncbi.nhl.nih.gov./BLAST) to find out the similarities with the genes DGAT1 in GenBank. The existence of mutations or SNPs (Single Nucleotide Polymorphism) in a sequence of fragments of genes DGAT1 was analyzed using the program on the Molecular Evolution of Genetic Analysis 6 (MEGA6) (Tamura et al. 2011). The diversity of the gene SNP DGAT1 is determined based on the frequencies of alleles and genotype, Hardy-Weinberg equilibrium is analyzed to use GENEPOP (V 3.2) (Raymond \& Rousset 2001).

\section{RESULTS AND DISCUSSION}

\section{Homology and mutation detection}

DGAT1 Exon 8 at Bali cattle generates PCR products which length is $383 \mathrm{bp}$ (Figure 1). A sample of the results of the sequencing was then verified through tracking and sequencing results of a Bos taurus with the access number AJ318490. Based on the comparison of the obtained results that sequence genes DGAT1 Bali cattle mutates $\mathrm{G} \rightarrow$ A on base 200 (c.10433) and C $\rightarrow$ A on base 201 (c.10434). The results of sequencing the 
genes DGAT1, shown in Figure 2. But in the Bali cattle population examined was not found differences or SNP. Single nucleotide polymorphism (SNP) is due to the difference of a single base substitution which polymorphism or diversity (Kwok \& Chan 2003). From these images in mind that Bali cattle has similarity with Bos taurus that has access to GenBank number AJ318490. The results of the analysis of the MEGA 6 stated that the SNP DGAT1 on Bali cattle which examined Single nucleotide Polymorphism is not found (SNP).

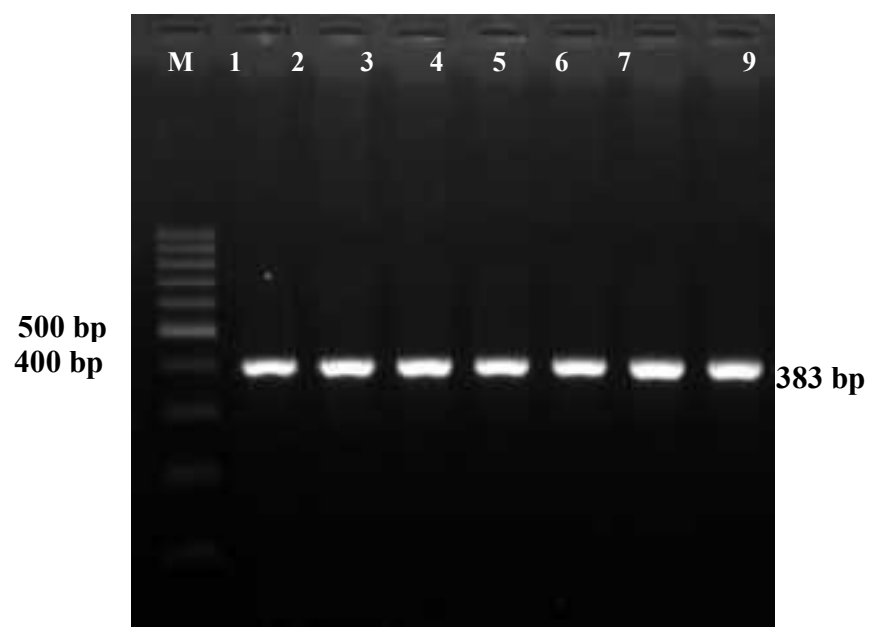

M: DNA marker $100 \mathrm{bp}$

Figure 1. Amplification DNA of DGAT1 gene on Bali cattle

In contrast to the study of Kong et al. (2007) in Korean cattle, two SNPs were found at the Exon and the same point was c. $10433 \mathrm{~A}>\mathrm{G}$ and c.10434A $>\mathrm{C}$. Research by Karolyi et al. (2012) states that SNP in DGAT1 gene in Exon 8 is a substitution between lysine $(\mathrm{K})$ base and alanine base (A) in the same position. These mutations can be categorized as non synonimous mutations because both codons (GCG and AAG) encode different amino acids namely alanine and lysine. According to Grisart et al. (2004) that the presence of polymorphisms from the DGAT1 gene in Black-and-White Holstein-Friesian cattle occurred due to mutations in the K232A nonconservation area which caused variations in marbling deposition. According to Moore et al. (2003) that marbling deposition depends on alleles encoding alanine and lysine at the base position 232 of the DGAT1 gene. The presence of alleles that encode lysine has been shown to be associated with increased marbling deposition rather than the presence of the alanine coding allele (A) which is associated with decreasing marbling deposition. 


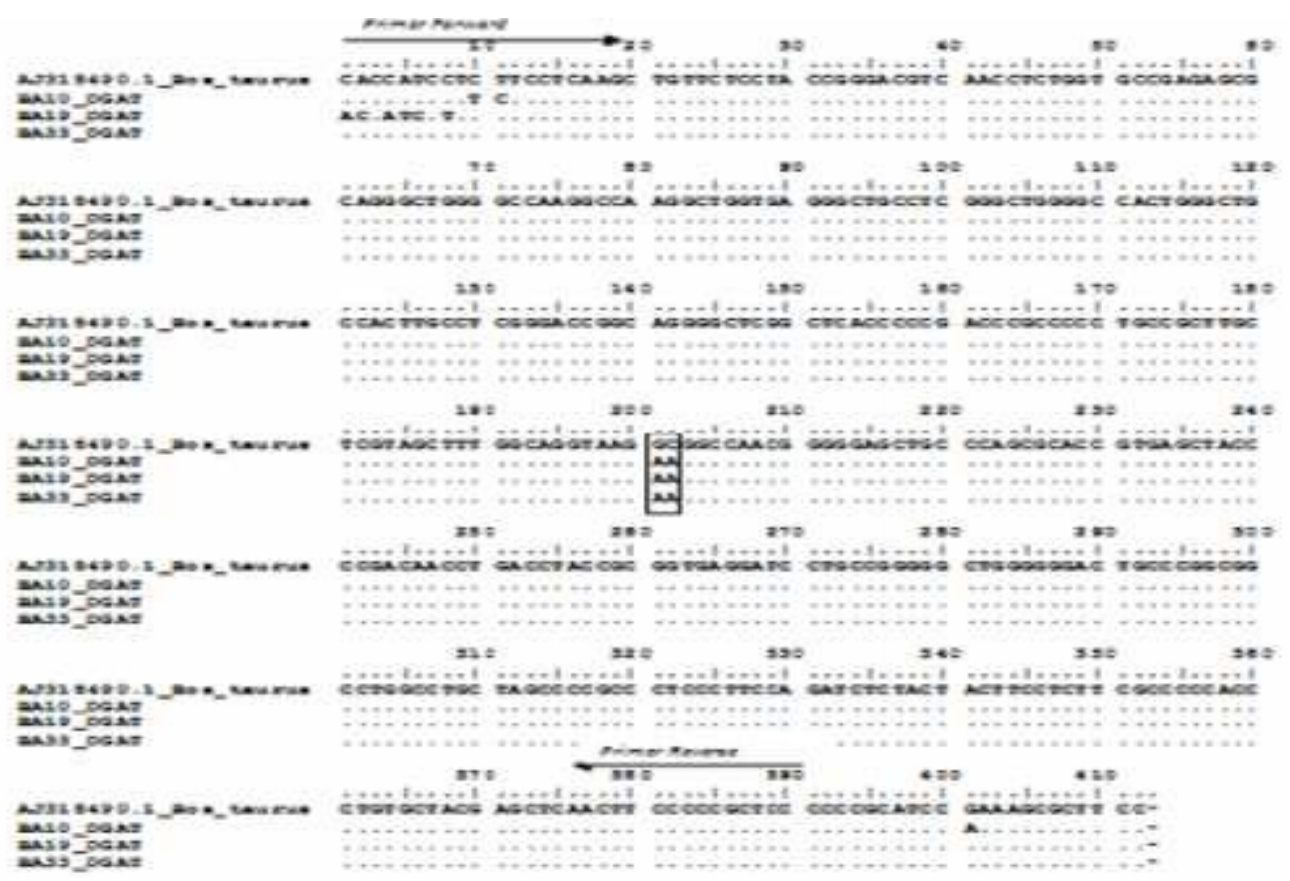

Figure 2. Sequencing analysis DGAT1 gene on Bali cattle dengan GenBank AJ318490

In contrast to the study of Kong et al. (2007) in Korean cattle, two SNPs were found at the Exon and the same point was c.10433A $>$ G and c.10434A $>$ C. Research by Karolyi et al. (2012) states that SNP in DGAT1 gene in Exon 8 is a substitution between lysine (K) base and alanine base (A) in the same position. These mutations can be categorized as non synonimous mutations because both codons (GCG and AAG) encode different amino acids namely alanine and lysine. According to Grisart et al. (2004) that the presence of polymorphisms from the DGAT1 gene in Black-and-White Holstein-Friesian cattle occurred due to mutations in the K232A nonconservation area which caused variations in marbling deposition. According to Moore et al. (2003) that marbling deposition depends on alleles encoding alanine and lysine at the base position 232 of the DGAT1 gene. The presence of alleles that encode lysine has been shown to be associated with increased marbling deposition rather than the presence of the alanine coding allele (A) which is associated with decreasing marbling deposition.

The SNP differences can be cattle at the location identifier. The effect of the existence of a base pair substitution simple on the SNP may be associated also with the nature or certain diseases (Schork et al. 2000). SNPS in the coding (Exon) have a direct impact on protein associated SNP in intron can affect splicing and SNP in the promoter can affect gene expression (Schork et al. 2000).

\section{Gene diversity}

The genotype frequency of DGAT1 genes on Bali cattle blood samples in this study produced two genotypes namely the AA genotype (100\%) in the sequence of the bases to the 201 and 202 to the base on the order have the genotype AA (100\%), so the frequency of A allele at bases 201 and 202 is 1.00 . The results of these studies are shown in Table 1. There is no $\mathrm{G}$ allele on a base 200 and $\mathrm{C}$ alleles at the order of the bases 201 . This means 
that there is no diversity that occurs on the DGAT1 genes Exon 8 in the Bali cattle. The DGAT1 genes on Bali cattle have allele frequency $G$ in base 200 and C in base 200 highest (1.00) so that it can be said that the DGAT1 genes in Bali cattle are uniform or monomorphic.

Table 1. Genotype frequency of DGAT1 Exon 8 in Bali Cattle

\begin{tabular}{lllllc}
\hline \hline DGAT1 gene & \multicolumn{3}{c}{ Genotype frequency } & \multicolumn{2}{c}{ Allele frequency } \\
\hline c.10433A $>$ G & AA (1.00) & $\begin{array}{l}\text { AG } \\
(0.00)\end{array}$ & GG (0.00) & A (1.00) & G (0.00) \\
c.10434A $>$ C & AA (1.00) & $\begin{array}{l}\text { AC } \\
(0.00)\end{array}$ & CC (0.00) & A (1.00) & C (0.00) \\
\hline
\end{tabular}

As for the DGAT gene Exon 8 fragments on a couple of different beef cattle on Table 2. From the results of the research note that the genes DGAT1 on Bali cattle are uniform or monomorfik because it only found one allele only i.e. A/a. Alleles A/A can be used as the specific allele of Bali cattle. The table explains that Bos javanicus (Bali cattle) has $100 \%$ of alleles A/A which encodes lysine. Bos indicus have frequencies of alleles $\mathrm{A} / \mathrm{A}$ (lysine) is higher when compared to the allele $\mathrm{G} / \mathrm{C}$ (alanin). But different things happen in Bos taurus, allele frequency is the highest of G/C, whereas A/A very little. Based on the results research Utama (2013) on the dairy cattle population in Balitnak and BIB Lembang that DGAT1 gene is polymorphic located on the 14th autosomal chromosome with a total length of 411 (base pairs), the amplicon is located at the 10th base position 232 to the 10th base 644.Alel obtained from this population are the $\mathrm{K}$ and $\mathrm{A}$ alleles. The results of the identification of DGAT1 gene segment diversity in the Center for Dairy Farming (BBPTUSP) Baturraden and Development Center Dairy Cattle Nursery (BPPT SP) Cikole, shows that the DGAT1 gene segment is polymorphic because there are two types of alleles, namely the K and A allele (Sari et al. 2014).

Tabel 2. Allele Frequency of DGAT1 gene on some cattle in the world

\begin{tabular}{|c|c|c|c|c|c|}
\hline \multirow{2}{*}{ Breed } & \multirow{2}{*}{$\mathrm{N}$} & \multicolumn{2}{|c|}{ Allele frequency } & \multirow{2}{*}{ Source } & \multirow{2}{*}{ Bos } \\
\hline & & $\mathrm{A} / \mathrm{A}$ & $\mathrm{G} / \mathrm{C}$ & & \\
\hline Bali Cattle & 48 & 1.000 & 0.000 & Research & Bos javanicus \\
\hline Minnan & 41 & 0.976 & 0.024 & Wu et al. (2011) & Bos indicus \\
\hline Bohai Black & 32 & 0.969 & 0.031 & Wu et al. (2011) & Bos indicus \\
\hline Leiqiong & 74 & 0.932 & 0.068 & Wu et al. (2011) & Bos indicus \\
\hline Yunnan High hump & 80 & 0.950 & 0.050 & Wu et al. (2011) & Bos indicus \\
\hline BMY & 81 & 0.722 & 0.278 & Wu et al. (2011) & Bos indicus \\
\hline Brahman & 16 & 0.780 & 0.220 & $\begin{array}{l}\text { Ripoli et al. } \\
\text { (2006) }\end{array}$ & Bos indicus \\
\hline Nelore & 10 & 0.800 & 0.200 & $\begin{array}{l}\text { Ripoli et al. } \\
\text { (2006) }\end{array}$ & Bos indicus \\
\hline Simmental & 26 & 0.170 & 0.830 & $\begin{array}{l}\text { Karolyi et al. } \\
\text { (2011) }\end{array}$ & Bos taurus \\
\hline Hanwoo & 200 & 0.250 & 0.750 & Kong et al. & Bos taurus \\
\hline
\end{tabular}




\begin{tabular}{|c|c|c|c|c|c|}
\hline \multirow{2}{*}{ Breed } & \multirow{2}{*}{$\mathrm{N}$} & \multicolumn{2}{|c|}{ Allele frequency } & \multirow{2}{*}{ Source } & \multirow{2}{*}{ Bos } \\
\hline & & $\mathrm{A} / \mathrm{A}$ & $\mathrm{G} / \mathrm{C}$ & & \\
\hline & & & & (2007) & \\
\hline Chinese Simmental & 132 & 0.106 & 0.894 & Wu et al. (2011) & Bos taurus \\
\hline Chinese Holstein & 192 & 0.260 & 0.740 & Wu et al. (2011) & Bos taurus \\
\hline Angus & 43 & 0.190 & 0.810 & Xin et al.(2013) & Bos taurus \\
\hline Charolais & 109 & 0.110 & 0.890 & Xin et al.(2013) & Bos taurus \\
\hline Hereford & 35 & 0.000 & 1.000 & Xin et al.(2013) & Bos taurus \\
\hline Limousin & 35 & 0.060 & 0.940 & Xin et al.(2013) & Bos taurus \\
\hline Simmental & 21 & 0.090 & 0.910 & Xin et al.(2013) & Bos taurus \\
\hline Fleckvieh bulls & 679 & 0.058 & 0.942 & $\begin{array}{l}\text { Barton et } \\
\text { al.(2016) }\end{array}$ & Bos taurus \\
\hline Holstein & 9 & 0.093 & 0.907 & $\begin{array}{l}\text { Ripoli et al. } \\
\text { (2006) }\end{array}$ & Bos taurus \\
\hline Jersey & 10 & 0.056 & 0.944 & $\begin{array}{l}\text { Ripoli et al. } \\
\text { (2006) }\end{array}$ & Bos taurus \\
\hline Charolais & 10 & 0.150 & 0.850 & $\begin{array}{l}\text { Ripoli et al. } \\
\text { (2006) }\end{array}$ & Bos taurus \\
\hline Angeln Dairy Cattle & 749 & 0.610 & 0.390 & $\begin{array}{l}\text { Sanders et al } \\
(2006)\end{array}$ & $\begin{array}{l}\text { B. taurus } \times B . \\
\text { indicus }\end{array}$ \\
\hline Piemontase & 990 & 0.300 & 0.700 & $\begin{array}{l}\text { Ribeca et al. } \\
(2015)\end{array}$ & $\begin{array}{l}\text { B. taurus } \times B \text {. } \\
\text { indicus }\end{array}$ \\
\hline Luxi & 40 & 0.872 & 0.128 & Wu et al. (2011) & $\begin{array}{l}\text { B. taurus } \times B \text {. } \\
\text { indicus }\end{array}$ \\
\hline $\begin{array}{l}\text { Girolando cattle }(3 / 8 \\
\text { Gir }+5 / 8 \text { Holstein })\end{array}$ & 349 & 0.540 & 0.460 & $\begin{array}{l}\text { Cardoso et al. } \\
\text { (2011) }\end{array}$ & $\begin{array}{l}B \text { indicus } \times B \\
\text { taurus }\end{array}$ \\
\hline Brangus & 8 & 0.380 & 0.620 & $\begin{array}{l}\text { Ripoli et al. } \\
(2006)\end{array}$ & $\begin{array}{l}\text { B. indicus } \times B \text {. } \\
\text { taurus }\end{array}$ \\
\hline Crole Argentine & 14 & 0.430 & 0.570 & $\begin{array}{l}\text { Ripoli et al. } \\
\text { (2006) }\end{array}$ & $\begin{array}{l}\text { B. indicus } \times B \text {. } \\
\text { taurus }\end{array}$ \\
\hline Crole Saavedreno & 106 & 0.360 & 0.640 & $\begin{array}{l}\text { Ripoli et al. } \\
\text { (2006) }\end{array}$ & $\begin{array}{l}\text { B. indicus } \times B \text {. } \\
\text { taurus }\end{array}$ \\
\hline Crole Chaqueno & 10 & 0.800 & 0.200 & $\begin{array}{l}\text { Ripoli et al. } \\
\text { (2006) }\end{array}$ & $\begin{array}{l}\text { B. } \text { indicus } \times B \text {. } \\
\text { taurus }\end{array}$ \\
\hline
\end{tabular}

\section{Heterozygosity}

Marson et al. (2005) stated that the genetic diversity of a population can be measured to use the value of heterozygosity is aimed at helping the program selection. The genes DGAT1 have low diversity based on the value of heterozigosity. The value of heterozygosity is indicating that the DGAT1 genes Exon 8 are not diverse $(0.00)$ on Bali cattle, because these genes have monomorphic AA allele. 


\section{CONCLUSION}

DGAT1 gene Exon 8 on Bali cattle have 2 SNPs, there are c.10433G $>$ A and c.10434C $>$ A. Allele frequency of there SNPs are 1.00. These genes have allele monomorphic AA. Heterozigosity and equilibrium value for this gene cannot counting because this SNPs are monomorphic.

\section{REFERENCES}

Badan Pusat Statistik Jakarta Pusat. 2017. Statistik Indonesia Tahun 2017. Jakarta (Indonesia): Badan Pusat Statistik.

Cardoso SR, Queuroz LB, Goulart VA, Mourao GB, Benedetti E, Goulart LR 2011. Productive performance of the dairy cattle Girolando breed mediated by the fat-related genes DGAT1 and LEP and their polymorphisms. J Vet Sci. 91:107-113.

DGLS. 2003. National Report on Animal Genetic Resources in Indonesia. Jakarta (Indonesia): Directorate General of Livestock Services.

Dewitri J, Merthayasa, I Ketut S, Kadek KA. 2015. Daya ikat air, pH, warna, bau dan tekstur daging sapi bali dan daging wagyu. J Indones Med Vet. 4:16-24.

Eko H, Subandriyo. 2004. Potensi dan keragaman sumberdaya genetik sapi Bali. Wartazoa. 14:107-115.

Grisart B, Farnir F, Karim L, Cambisano N, Kim J-J, Kvasz A, Mni M, Simon P, Frère J-M, Coppieters W, Georges M. 2004. Genetic and functional confirmation of the causality of the DGAT1 K232A quantitative trait nucleotide in affecting milk yield and composition. Proc Natl Acad Sci USA. 101:2398-2403.

Kong JHS, Oh D, Lee JH, Yoon DH, Choi YH, Cho BW, Lee HK, Jeon GJ. 2007. Association of Sequence Variations in DGAT 1 Gene with Economic Traits in Hanwoo (Korea Cattle). Asian-Aust. J Anim Sci. 20:817-820.

Marson EP, Ferraz JBS, Meirelles FV, Balieiro JCC, Eler JP, Figuerido LGG, Mourao GB. 2005. Genetic characterization of European-Zebu composite bovine using RFLP markers. J Genet Mol Res. 4:496-505.

Moore SS, C Li, J Basarab, WM Snelling, J Kneeland, B Murdoch, C Hansen, B Benkel. 2003. Fine mapping of quantitative trait loci and assessment of positional candidate genes for backfat on bovine chromosome 14 in a commercial line of Bos taurus. J Anim Sci. 81:1919-1925.

Raymond M, Rousset F. 2001. Genepop (3.3). Population Genetics Software for Exact Tests and Ecumenicism (EB/OL). Available at (http:www:wbiomed.curtin.edu.au/ genepop).

Ribeca C, Bonfatti V, Cecchinato A, Albera A, Gallo L, Camier P. 2014. Effect of polymorphisms in candidate genes on carcass and meat quality traits in double muscled Piemontese cattle. J Meat Sci. 96:1376-1383.

Ripoli MV, Corva P, Giovambatista G. 2006. Analysis of a polymorphism in the DGAT1 gene in 14 cattle breeds through PCR-SSCP methods. J Vet Sci. 80:287-290.

Asmarasari SA, Sumantri C, Mathius I, Anggraeni A. 2014. Polimorfisme gen diasilgliserol asiltransferase 1 dan asosiasinya dengan komponen asam lemak susu sapi perah Friesian Holstein. JITV. 19:159-167.

Soeparno. 2005. Ilmu dan Teknologi Daging Cetakan Keempat. Yogyakarta (Indonesia): Gadjah Mada University Press 
Talib C. 2002. Sapi Bali di daerah sumber bibit dan peluang pengembangannya. Wartazoa. 12:100-107.

Tamura K, Peterson D, Peterson N, Stecher G, Nei M, Kumar S. 2011. MEGA5: molecular evolutionary genetics analysis using maximum likelihood. evolutionary distance. and maximum parsimony methods. J Mol Biol Evol. 28:2731-2739.

Thaller G, Kramer W, Winter A, Kaupe B, Erhardt G, Fries R. 2003. Effects of DGAT1 variants on milk production traits in German cattle breeds. J Anim Sci. 81:1911-1918.

Utama R. 2013. Identifikasi Keragaman Gen Dgat1|Eaei pada sapi Friesian Holstein dengan Metode PCR-Rflp. [Skripsi]. Bogor (Indonesia): Institut Pertanian Bogor.

Winter A, Krämer W, Werner FAO, Kollers S, Kata S, Durstewitz G, Buitkamp J, Womack JE, Thaller G, Fries R. 2002. Association of a lysine-232/alanine polymorphism in a bovine gene encoding acyl CoA: diacylglycerol acyltransferase DGAT1 with variation at a quantitative trait locus for milk fat content. Proc Natl Acad Sci USA. 99:9300-9305.

Wu XX, Yang ZP, Shi XK, Li JY, Ji DJ, Mao YJ, Chang L., Gao HJ. (2012). Association of SCD1 and DGAT1 SNPs with the intramuscular fat traits in Chinese Simmental cattle and their distribution in eight Chinese cattle breeds. J Mol Biol Rep. 39:1065-1071.

Li X, Ekerljung M, Lundström K, Lundén A. 2013. Association of polymorphisms at DGAT1, leptin, SCD1, CAPN1 and CAST genes with color, marbling and water holding capacity in meat from beef cattle populations in Sweden. Sweden (SD). Meat Sci. 94:153-158. 